\title{
Fennema - Sherman Mathematics Attitude Scales: Adaptaition to Turkish Culture*
}

\author{
Mithat TAKUNYACI** \\ Melek MASAL
}

\author{
Ercan MASAL ${ }^{* * *}$ \\ Özkan ERGENE ${ }^{* * * *}$
}

Kübra ERDEN ${ }^{* * * * *}$

\begin{abstract}
The aim of this study is to adapt the Fennema-Sherman Mathematics Attitude Scales developed by Fennema and Sherman in 1976 to Turkish language and culture. Data were collected from 1123 middle-school students and 967 highschool students a in order to adapt the scale to Turkish culture. The scale was first translated from its original version in English to Turkish by three linguists, and then the translation was revised upon consultation with two domain experts and one measurement and evaluation expert. None of the scale items were discarded during these stages. The construct validity of the Turkish translation of the scale was examined using exploratory and confirmatory factor analysis and reliability analysis was conducted using Item Analysis, Cronbach's Alpha, internal consistency coefficient, and split-half correlation. Exploratory factor analysis and reliability calculations were conducted on SPSS 20.0, and the confirmatory factor analysis calculations were conducted on the Lisrel 8.7 software package. Following the validity and reliability studies, the scale is composed of nine subscales and 108 items as in the original form. As a result of the adaptation of the FennemaSherman Mathematics Attitude Scales, a valid and reliable scale suitable for Turkish and Turkish cultures was obtained.
\end{abstract}

Keywords: Fennema-Sherman, attitude towards learning mathematics, scale adaptation.

\footnotetext{
* This study was presented in three parts as an oral presentation in ERPA 2018 and ICSE 2018 and published in book of abstracts.

** Orcid ID: https://orcid.org/0000-0003-1065-975X, Assist. Prof. Dr., Sakarya University, Elementary Mathematics Education, mtakunyaci@sakarya.edu.tr

*** Orcid ID: https://orcid.org/0000-0001-8351-7248, Assist. Prof. Dr., Sakarya University, Elementary Mathematics Education, emasal@sakarya.edu.tr

**** Orcid ID: https://orcid.org/0000-0001-6712-7629, Assoc. Prof. Dr., Sakarya University, Elementary Mathematics Education, mmasal@sakarya.edu.tr

***** Orcid ID: https://orcid.org/0000-0001-5119-2813, Ress. Assist. Dr., Sakarya University, Elementary Mathematics Education, ozkanergene@sakarya.edu.tr

****** Orcid ID: https://orcid.org/0000-0002-9332-5765, Master Student, Sakarya University, Institute of Educational Sciences.
} 


\section{INTRODUCTION}

Although there has not been a standard definition of "attitude" in the literature, in general, the term attitude has been defined as an emotional tendency that has been organised by experience, and that has been learned to positively or negatively respond to an object, situation, concept or a person, and as mental and neural readiness (Aiken, 1970; Khine and Afari, 2014, Lim, 2012; Triandis, 1971).

Attitudes towards learning mathematics consist of likes or dislikes of mathematics, the desire to participate in or tendency to refrain from mathematical activity, beliefs about mathematics' being good or bad, useful or useless. Although the structure of attitude is not clearly defined, an implicit definition is introduced through the identification of the factors it contains. While attitude, as a term, is sometimes used to mean as the level of pleasure, interest or anxiety (Aiken, 1972), researches on attitude comprise of research based on beliefs and values (Wigfield \& Eccles, 2000), emotional reactions and confidence (Felder, Felder, Mauney, Hamrin and Dietz, 1995), and on self-efficacy or anxiety (Ross, 2015). The pleasure in doing mathematics, self-confidence in mathematics, and the perceived value of mathematics have either remained constant in the definitions of attitude towards learning Mathematics in the last 50 years (Aiken, 1970; Fennema and Sherman, 1976; Neale, 1969) or they have been barely changed (Etsey \& Snetzler, 1998; Ma \& Kishor, 1997; Tapia, 1996).

Although there are many instruments developed to determine attitude in general, there are not sufficient instruments having well defined dimensions especially related to mathematics learning. When the scale development studies in Turkey were examined (Aşkar, 1986; Erol, 1989; Baykul, 1990), it was seen that developed scales are attitude towards mathematics scales. On the other hand, Fennema-Sherman Mathematics Attitude Scale developed by Fennema and Sherman (1976) evaluates students' attitudes towards mathematics from different perspectives.

Fennema-Sherman Math Attitude Scales (FSMAS) were developed to reveal the genderrelated differences between high school male and female students in their attitudes towards mathematics and they have been used extensively in studies on gender differences in learning outcomes of mathematics. Each of them consists of 9 scales measuring the field-specific attitudes related to mathematics learning. In short, these scales are;

- Mathematics Anxiety Scale (A) is used to measure feelings of anxiety, fear, nervousness and body symptoms related to doing mathematics,

- Scale of Confidence in Learning Mathematics (C) is used to measure individual's confidence in learning mathematical tasks well and self-confidence in performing well in mathematical tasks, 
- Scale of Perceived Usability of Mathematics (U) is used to measure students' beliefs about the usability of mathematics in relation to their present and future education,

- Scale of Effective Motivation in Mathematics (E) is used to measure individuals' level of willingness to participate in mathematical activities and to measure their level of internal favour or disfavour of this participation,

- Scale of Attitude towards Achievement in Mathematics (AS) is used to measure the degree of positive or negative results predicted by individuals as a result of achievement in mathematics,

- Scale for Mathematics as a Field of Study for Males (MD) is used to measure how gender groups perceive mathematics from the point of their mathematical abilities and achievements,

- Mother (M) - Father (F) Scale is used to measure how students perceive both their own and their parents' interest, incentives, encouragement in mathematics and awareness about the importance of mathematics.

- Teacher Scale (T) is used to measure the teachers' attitudes (teacher's interest, encouragement and trust on student ability) towards students as mathematics learners.

After Fennema and Sherman (1976) published their findings from FSMAS, FSMAS has been frequently used by researchers studying gender factor in mathematics education and their article has been among the most cited articles in mainstream journals of educational psychology (Walberg and Haertel, 1992). Although several aspects of MD may be no longer valid in recent years (except for items on the other eight scales of FSMAS), MD remains a variable of gender difference.

Because we are in a new age of literacy, which requires mathematical competence as a prerequisite for adaptation to the inevitable reality of a technology-based global economy and the increasing technological demands of the society, it is essential that the variables related to proficiency in mathematics and participation in mathematical tasks for both men and women should be profoundly understood. Many countries face the problem of not having adequate representation of women in the STEM areas, and in fact since the early 1970s there has been persevering studies on this problem. (LeGrand, 2013; Leslie, Cimpian, Meyer and Freeland, 2015, Kanny, MA, Sax, LJ, Riggers-Pieh, TA. 2014). In a study, which surveys the studies carried on between 1970s and 2000s, Kanny et al. (2014) explain gender deficits in STEM fields under five categories; individual background characteristics, structural barriers in K-12 education, psychological factors, family effects-expectations and perception of STEM fields. As an aspect of the psychological category, they concluded that self-confidence was the variable that explained the gender factor in STEM fields the best (Kanny et al. 2014). 
It is known that motivation and participation of students have a direct effect on their academic success, and that students with positive attitude towards mathematics have a higher achievement in mathematics (Johnson, 2000; Tapia and Marsh, 2000). According to results of Turkey TIMSS 2015, when students from 4th grade are compared to the students from 8th grade by their affection in learning, self-confidence and participation in lessons, 8th graders show a serious decline in all these attitudes (Yldırım, Yıldırım, and Ceylan, 2017). From this point of view, it can be stated that these attitudes have deteriorated over time. Likewise, according to results of OSYM placements, out of 1000 students who were placed in STEM fields between the years 2000 and 2014 depending on their exam results in mathematic related tests, $81,39 \%$ of the students are male and $18,61 \%$ of the students are female. If Medical Faculties - despite the fact that they are not one of the STEM fields- are included in the statistics, it is seen that an average of $71.42 \%$ of males and $28.58 \%$ of females were placed in STEM fields (Aydeniz, Cakmakcl, Cavas, Ozdemir, Akgunduz, Corlu, \& Oner, 2015).

In conclusion, it seems reasonable to assume the hypothesis that adolescence, during when the sexual role awareness transmitted by the peers increases, is the period when both males' and females' attitudes towards and performance in mathematics begin to differ from each other.

Separate studies to adapt the FSMAS scale for secondary school and high school students are important to determine when students start developing negative attitudes towards mathematics. The adapted scales are important for further studies to enable timely intervention for preventing students from developing those negative attitudes and for ensuring more STEM participation.

\section{METHOD}

\section{Original Scale}

The Fennema-Sherman Mathematics Attitude Scales (FSMAS), developed by Fennema and Sherman (1976) to reveal the gender-based differences between mathematics attitudes of high-school students, were applied. FMAS consists of 108 items grouped under 9 subscales, namely; Mathematics Anxiety Scale (A), The Confidence in Learning Mathematics Scale (C), Perceived Usefulness of Mathematics Scale (U), Effective Motivation Scale in Mathematics (E), Attitude toward Success in Mathematics Scale (AS), Mathematics as a Male Domain Scale (MD), and Mother (M) - Father (F) - Teacher (T) Scale. Each subscale, in turn, is composed of 6 positive and 6 negative items, thus a total of 12 items, expressed in 5 point Likert Scale, where the straightforward responses are coded as "Strongly Agree = 5", "Agree = 4", "Undecided = 3", "Disagree = 2", and "Strongly Disagree $=1$ ". All subscales can be applied individually (Ganley \& Vasilyeva, 2011). Some example items are given at attachment. 


\section{Translation of the Scale to Turkish}

The scale was first translated from its original version in English to Turkish by three linguists, and then the translation was revised upon consultation with two domain experts and one measurement and evaluation expert. None of the scale items were discarded during these stages. The revised scale contains 9 different subscales and 108 items. The construct validity of the Turkish translation of the scale was examined using exploratory and confirmatory factor analysis and reliability analysis was conducted using Item Analysis, Cronbach's Alpha, internal consistency coefficient, and split-half correlation. Exploratory factor analysis and reliability calculations were conducted on SPSS 20.0, and the confirmatory factor analysis calculations were conducted on the Lisrel 8.7 software package.

\section{Participants}

The data were collected from 967 high-school students who are all schooled in a district of Sakarya province of Turkey. Of the participating students; 383 (39.6\%) attend 9th grade, $310(32.1 \%)$ attend 10th grade, 177 (18.3\%) attend 11th grade, and $97(10 \%)$ attend 12 th grade. Within the group of students to whom the scale was applied, 398 (41.2\%) are male, and 569 (58.8\%) are female students.

Table 1a.

Gender and grade distribution of High-School students participating in the study

\begin{tabular}{lcccccccccc}
\hline & \multicolumn{2}{c}{$9 . G r a d e$} & \multicolumn{2}{c}{$10 . G r a d e$} & \multicolumn{2}{c}{$11 . G r a d e$} & \multicolumn{2}{c}{12. Grade } & \multicolumn{2}{c}{ Total } \\
\hline Gender & $\mathrm{N}$ & $\%$ & $\mathrm{~N}$ & $\%$ & $\mathrm{~N}$ & $\%$ & $\mathrm{~N}$ & $\%$ & $\mathrm{~N}$ & $\%$ \\
\hline Male & 148 & 37.2 & 158 & 39.7 & 43 & 10.8 & 49 & 12.3 & 398 & 41.2 \\
Female & 235 & 41.3 & 152 & 26.7 & 134 & 23.6 & 48 & 8.4 & 569 & 58.8 \\
\hline Total & 383 & 39.6 & 310 & 32.1 & 177 & 18.3 & 97 & 10 & 967 & 100 \\
\hline
\end{tabular}

The data were collected from 1123 middle-school students who are all schooled in a district of Sakarya province of Turkey. Of the participating students; 49 (4.4\%) attend 5 th grade, 396 (35.3\%) attend 6th grade, 280 (24.9\%) attend 7th grade, and 398 $(35.4 \%)$ attend 8 th grade. Within the group of students to whom the scale was applied, $492(43.8 \%)$ are male, and $631(56.2 \%)$ are female students. 
Table $1 \mathrm{~b}$.

Gender and grade distribution of middle-school students participating in the study

\begin{tabular}{lcccccccccc}
\hline & \multicolumn{2}{c}{$5 . G r a d e$} & \multicolumn{2}{c}{ 6.Grade } & \multicolumn{2}{c}{ 7.Grade } & \multicolumn{2}{c}{ 8.Grade } & \multicolumn{2}{c}{ Total } \\
\hline Gender & $\mathrm{N}$ & $\%$ & $\mathrm{~N}$ & $\%$ & $\mathrm{~N}$ & $\%$ & $\mathrm{~N}$ & $\%$ & $\mathrm{~N}$ & $\%$ \\
\hline Male & 23 & 46.9 & 163 & 41.2 & 136 & 48.6 & 170 & 42.7 & 492 & 43.8 \\
Female & 26 & 53.1 & 233 & 58.8 & 144 & 51.4 & 228 & 57.3 & 631 & 56.2 \\
\hline Total & 49 & 4.4 & 396 & 35.3 & 280 & 24.9 & 398 & 35.4 & 1123 & 100
\end{tabular}

\section{Data Analysis}

Reliability and validity analysis of the scale were tested separately for the two different sample groups. For the high-school sample group; validity and reliability analysis were conducted based on the 9 subscales of the Fennema-Sherman Mathematics Attitude Scales (FSMAS). When conducted as a whole, it takes approximately 45 minutes for participants to answer all 108 items of the FSMAS. Considering that this duration might reflect negatively on the attention span of participants (Mulhern \& Rae, 1998), only 6 subscales with the exception of Mathematics Anxiety Scale (A), Attitude toward Success in Mathematics Scale (AS) and Mathematics as a Male Domain (MD) were applied to middle-school sample group; and the validity and reliability analysis were conducted only for these subscales.

In order to examine the construct validity of Turkish translation of the scale, initially the Exploratory Factor Analysis (EFA) was conducted. Following the exploratory factor analysis, the Confirmatory Factor Analysis (CFA) was applied with a view to test the model compliance of the scale. Item total correlation and comparison of lower and upper approximations were used as item analysis methods in the analysis of items to be included in the scale. Internal consistency and split-half methods were conducted to determine the reliability of the scale. Cronbach's alpha internal consistency coefficient was calculated in the determination of reliability by internal consistency method. The SPSS 20 software package program was used in data analysis while Lisrel 8.7 software package program was employed in confirmatory factor analysis.

\section{FINDINGS}

\section{Validity Analysis}

\section{Exploratory Factor Analysis (EFA)}

Prior to the conduction of EFA on scale items, the Kaiser-Meyer-Olkin (KMO) test, which determines whether the sample count is sufficient for analysis was conducted and the compliance of data with factor analysis was determined. The findings of abovementioned tests as well as of the Bartlett's Test of Sphericity are provided in Table 2. 
Table 2.

Findings of the KMO and Bartlett's Test of Scales

\begin{tabular}{|c|c|c|c|c|}
\hline \multirow[b]{2}{*}{ Sub-scales } & \multicolumn{2}{|c|}{ High School Sample } & \multicolumn{2}{|c|}{ Middle School Sample } \\
\hline & KMO & $\begin{array}{c}\text { Bartlett } \\
\text { Sphericity Test }\end{array}$ & KMO & $\begin{array}{c}\text { Bartlett } \\
\text { Sphericity Test }\end{array}$ \\
\hline $\begin{array}{l}\text { Attitude Toward Success in } \\
\text { Mathematics, (AS) }\end{array}$ & .83 & $2266.01^{*}$ & - & - \\
\hline $\begin{array}{l}\text { Mathematics as a Male Domain, } \\
\text { (MD) }\end{array}$ & .80 & $1907.77^{*}$ & - & - \\
\hline Mother Scale, (M) & .81 & $2090.74^{*}$ & .79 & $2188.36^{*}$ \\
\hline Father Scale, (F) & .84 & $2411.52^{*}$ & .82 & $3211.18^{*}$ \\
\hline Teacher Scale, (T) & .77 & 1339.09* & .74 & $1966.34 *$ \\
\hline Confidence Scale, (C) & .88 & $3052.75^{*}$ & .80 & $3422.32^{*}$ \\
\hline Mathematics Anxiety Scale, (A) & .85 & $2528.23^{*}$ & - & - \\
\hline Effectance Motivation, (E) & .83 & 1976.69* & .82 & $3792.65^{*}$ \\
\hline $\begin{array}{l}\text { Mathematics Usefulness Scale, } \\
\text { (U) }\end{array}$ & .85 & $2674.16^{*}$ & .80 & $2654.73^{*}$ \\
\hline
\end{tabular}

Based on the findings provided in Table 2, the KMO value above .60 and the statistically significant outcome of the Bartlett's test imply that the data are suitable for factor analysis and that factor analysis can be conducted (Kaiser, 1974; Bartlett, 1950).

In accordance with analysis results, the 9 scales are uni-dimensional and consist of 12 items as per their original version. Factor loadings indicate the correlation between the items and the construct to be scaled. The study required a loading of at least 0.30 on any factor for an item to be allocated to a specific factor (Büyüköztürk, 2013). The EFA conducted on data collected from high-school and middle-school sample groups concluded that items in each subscale were loaded above .30, and also concluded that their explained variance values were at least $30 \%$. At least $30 \%$ explained variance value is considered sufficient for uni-dimensional scales (Büyüköztürk, 2013). 
Table 3.

Factors loadings and explained variance ratios of scales

\begin{tabular}{lcccc}
\hline & \multicolumn{2}{c}{ High School Sample } & \multicolumn{2}{c}{ Middle School Sample } \\
\hline Sub-scales & $\begin{array}{c}\text { Factor } \\
\text { Loading }\end{array}$ & $\begin{array}{c}\text { Explained } \\
\text { Variance }\end{array}$ & $\begin{array}{c}\text { Factor } \\
\text { Loading }\end{array}$ & $\begin{array}{c}\text { Explained } \\
\text { Variance }\end{array}$ \\
\hline $\begin{array}{l}\text { Attitude Toward Success in } \\
\text { Mathematics (AS) }\end{array}$ & $.45-.73$ & $\% 42.23$ & - & - \\
Mathematics as a Male & $.45-.76$ & $\% 40.41$ & - & - \\
Domain (MD) & $.38-.72$ & $\% 41.17$ & $.43-.69$ & $\% 45.66$ \\
Mother Scale (M) & $.55-.72$ & $\% 43.53$ & $.48-.70$ & $\% 49.83$ \\
Father Scale (F) & $.47-.68$ & $\% 36.26$ & $.43-.64$ & $\% 41.77$ \\
Teacher Scale (T) & $.47-.78$ & $\% 46.23$ & $.46-.70$ & $\% 48.54$ \\
Confidence Scale (C) & $.39-.70$ & $\% 43.95$ & - & - \\
$\begin{array}{l}\text { Mathematics Anxiety Scale } \\
\text { (A) }\end{array}$ & $.38-.66$ & $\% 39.71$ & $.54-.66$ & $\% 51.79$ \\
Effectance Motivation (E) & $.56-.68$ & $\% 44.36$ & $.47-.53$ & $\% 49.35$ \\
Mathematics Usefulness & & & & \\
Scale (U) & & & & \\
\hline
\end{tabular}

\section{Confirmatory Factor Analysis (CFA)}

The CFA was conducted toverify and determine the of factor structure of the scale with the collected data, and the fit indices and values are provided in Table 4 below. The $\chi 2 /$ df ratio calculated to be lower than 3 , and particularly the GFI and AGFI values above .90 indicate model and data compliance (Jöreskog \& Sörbom, 1993). These values indicated that the observed construct of the scale was compatible with the expected construct. 
Table 4.

CFA Results

\begin{tabular}{|c|c|c|c|}
\hline Scales & $\begin{array}{l}\text { High School Sample } \\
\text { Fit Indices and Values }\end{array}$ & $\begin{array}{l}\text { Middle School Sample } \\
\text { Fit Index and Values }\end{array}$ & $\begin{array}{l}\text { Acceptable Fit } \\
\text { Values }\end{array}$ \\
\hline $\begin{array}{l}\text { Attitude } \\
\text { Toward } \\
\text { Success in } \\
\text { Mathematics } \\
\text { (AS) }\end{array}$ & $\begin{array}{l}\chi^{2} / \mathrm{sd}=2.78 \\
\mathrm{RMSEA}=.069 \\
\mathrm{GFI}=.92, \mathrm{AGFI}=.93 \\
\mathrm{CFI}=.96, \text { ve } \mathrm{NFI}=.90\end{array}$ & - & $\begin{array}{l}<5 \\
<.08 \\
>.90,>.90 \\
>.90,>.90\end{array}$ \\
\hline $\begin{array}{l}\text { Mathematics } \\
\text { as a Male } \\
\text { Domain } \\
\text { (MD) }\end{array}$ & $\begin{array}{l}\chi^{2} / \mathrm{sd}=2.54 ; \mathrm{RMSEA}=.072, \\
\mathrm{GFI}=.90, \mathrm{AGFI}=.90 \\
\mathrm{CFI}=.95, \text { ve } \mathrm{NFI}=.92\end{array}$ & - & $\begin{array}{l}<5 \\
<.08 \\
>.90,>.90 \\
>.90,>.90\end{array}$ \\
\hline $\begin{array}{l}\text { Mother Scale } \\
\text { (M) }\end{array}$ & $\begin{array}{l}\chi^{2} / \mathrm{sd}=2.06 ; \mathrm{RMSEA}=.061, \\
\mathrm{GFI}=.91, \mathrm{AGFI}=.91 \\
\mathrm{CFI}=.94, \text { ve } \mathrm{NFI}=.95\end{array}$ & $\begin{array}{l}\chi^{2} / \mathrm{sd}=2.45 ; \\
\mathrm{RMSEA}=.045, \mathrm{GFI}=.92, \\
\mathrm{AGFI}=.91, \mathrm{CFI}=.94, \mathrm{ve} \\
\mathrm{NFI}=.94\end{array}$ & $\begin{array}{l}<5 \\
<.08 \\
>.90,>.90 \\
>.90,>.90\end{array}$ \\
\hline $\begin{array}{l}\text { Father Scale } \\
\text { (F) }\end{array}$ & $\begin{array}{l}\chi^{2} / \mathrm{sd}=2.92 ; \mathrm{RMSEA}=.067 \\
\mathrm{GFI}=.91, \mathrm{AGFI}=.91 \\
\mathrm{CFI}=.97, \text { ve } \mathrm{NFI}=.90\end{array}$ & $\begin{array}{l}\chi^{2} / \mathrm{sd}=1.88 \\
\mathrm{RMSEA}=.035, \mathrm{GFI}=.91 \\
\mathrm{AGFI}=.91, \mathrm{CFI}=.93, \mathrm{ve} \\
\mathrm{NFI}=.91\end{array}$ & $\begin{array}{l}<5 \\
<.08 \\
>.90,>.90 \\
>.90,>.90\end{array}$ \\
\hline $\begin{array}{l}\text { Teacher } \\
\text { Scale (T) }\end{array}$ & $\begin{array}{l}\chi^{2} / \mathrm{sd}=2.32 ; \mathrm{RMSEA}=.058 \\
\mathrm{GFI}=.96, \mathrm{AGFI}=.91 \\
\mathrm{CFI}=.96, \mathrm{ve} \mathrm{NFI}=.89\end{array}$ & $\begin{array}{l}\chi^{2} / \mathrm{sd}=2.92 ; \\
\mathrm{RMSEA}=.041, \mathrm{GFI}=.90 \\
\mathrm{AGFI}=.90, \mathrm{CFI}=.95, \mathrm{ve} \\
\mathrm{NFI}=.88\end{array}$ & $\begin{array}{l}<5 \\
<.08 \\
>.90,>.90 \\
>.90,>.90\end{array}$ \\
\hline $\begin{array}{l}\text { Confidence } \\
\text { Scale (C) }\end{array}$ & $\begin{array}{l}\chi^{2} / \mathrm{sd}=2.19 ; \mathrm{RMSEA}=.073 \\
\mathrm{GFI}=.90, \mathrm{AGFI}=.93 \\
\mathrm{CFI}=.96, \mathrm{ve} \mathrm{NFI}=.92\end{array}$ & $\begin{array}{l}\chi^{2} / \mathrm{sd}=2.45 \\
\mathrm{RMSEA}=.045, \mathrm{GFI}=.92, \\
\mathrm{AGFI}=.92, \mathrm{CFI}=.94, \mathrm{ve} \\
\mathrm{NFI}=.94\end{array}$ & $\begin{array}{l}<5 \\
<.08 \\
>.90,>.90 \\
>.90,>.90\end{array}$ \\
\hline
\end{tabular}




\begin{tabular}{|c|c|c|c|}
\hline \multirow[b]{2}{*}{$\begin{array}{l}\text { Mathematics } \\
\text { Anxiety } \\
\text { Scale (A) }\end{array}$} & \multirow[b]{2}{*}{$\begin{array}{l}\chi^{2} / \mathrm{sd}=2.32 ; \mathrm{RMSEA}=.067 \\
\mathrm{GFI}=.93, \mathrm{AGFI}=.90 \\
\mathrm{CFI}=.93, \text { ve } \mathrm{NFI}=.89\end{array}$} & & \multirow[b]{2}{*}{$\begin{array}{l}<5 \\
<.08 \\
>.90,>.90 \\
>.90,>.90\end{array}$} \\
\hline & & & \\
\hline $\begin{array}{l}\text { Effectance } \\
\text { Motivation } \\
\text { (E) }\end{array}$ & $\begin{array}{l}\chi^{2} / \mathrm{sd}=1.98 ; \mathrm{RMSEA}=.075 \\
\mathrm{GFI}=.92, \mathrm{AGFI}=.90 \\
\mathrm{CFI}=.97, \text { ve } \mathrm{NFI}=.90\end{array}$ & $\begin{array}{l}\chi^{2} / \mathrm{sd}=1.88 ; \\
\mathrm{RMSEA}=.035, \mathrm{GFI}=.91 \\
\mathrm{AGFI}=.91, \mathrm{CFI}=.93, \mathrm{ve} \\
\mathrm{NFI}=.91\end{array}$ & $\begin{array}{l}<5 \\
<.08 \\
>.90,>.90 \\
>.90,>.90\end{array}$ \\
\hline $\begin{array}{l}\text { Mathematics } \\
\text { Usefulness } \\
\text { Scale (U) }\end{array}$ & $\begin{array}{l}\chi^{2} / \mathrm{sd}=2.37 \\
\mathrm{RMSEA}=.072 \\
\mathrm{GFI}=.90, \mathrm{AGFI}=.92, \\
\mathrm{CFI}=.96, \text { ve } \mathrm{NFI}=.91\end{array}$ & $\begin{array}{l}\chi^{2} / \mathrm{sd}=2.92 ; \\
\mathrm{RMSEA}=.041, \mathrm{GFI}=.90 \\
\mathrm{AGFI}=.90, \mathrm{CFI}=.95, \mathrm{ve} \\
\mathrm{NFI}=.88\end{array}$ & $\begin{array}{l}<5 \\
<.08 \\
>.90,>.90 \\
>.90,>.90\end{array}$ \\
\hline
\end{tabular}

\section{Item Analysis}

\section{Item Total Correlations}

The Item Total Correlations refer to the correlation between the points of individual test items and the total points of the test. Positive and high Item Total Correlation indicates that items sample similar behaviour and that, subsequently, the internal consistency of the test is substantial (Büyüköztürk, 2013).

The Item Total Correlation analysis on scale items indicates that item total correlation in high-school sample group ranges between .34 and .68, while for middle-school sample group, it ranges between .41 and .56. Items of .30 or above item total correlation mean that they are compatible to measure the behaviour they refer to (Büyüköztürk, 2013). Findings concluded that for each sample group, the item total correlation value is above .30. This conclusion also indicates that internal consistency of scales is achieved.

Two individual groups were formed of the lower $27 \%$ and upper $27 \%$ segments of points obtained from scales and their average item points were subjected to the Independent Samples T-Test; the significant difference calculated as a result indicates that the scale quite efficiently differentiates between the individuals of measurable qualities and individuals of immeasurable qualities (Büyüköztürk, 2013). The T-Test findings of the item point comparisons of the groups of lower $27 \%$ and upper $27 \%$ are demonstrated in Table 5. 
Table 5.

T-test findings of the groups of Lower 27\% and Upper 27\% of Scales

\begin{tabular}{|c|c|c|c|c|}
\hline \multirow[b]{2}{*}{ Sub-Scales } & \multicolumn{2}{|c|}{$\begin{array}{l}\text { High School } \\
\text { Sample }\end{array}$} & \multicolumn{2}{|c|}{ Middle School Sample } \\
\hline & Min. & Maks. & Min. & Maks. \\
\hline $\begin{array}{l}\text { Attitude Toward Success in } \\
\text { Mathematics (AS) }\end{array}$ & -11.78 & -2.33 & - & - \\
\hline Mathematics as a Male Domain (MD) & -14.43 & -2.62 & - & - \\
\hline Mother Scale (M) & -9.87 & -5.83 & 11.33 & -3.56 \\
\hline Father Scale (F) & -10.21 & -7.45 & -5.67 & 4.93 \\
\hline Teacher Scale (T) & -13.33 & -2.17 & -9.82 & -7.44 \\
\hline Confidence Scale (C) & -7.45 & -3.98 & 10.92 & -6.78 \\
\hline Mathematics Anxiety Scale (A) & -11.05 & -4.61 & - & - \\
\hline Effectance Motivation, (E) & -8.41 & -3.48 & -8.83 & -4.65 \\
\hline Mathematics Usefulness Scale (U) & -10.01 & -5.36 & $\begin{array}{c}- \\
10.67\end{array}$ & -7.01 \\
\hline
\end{tabular}

\section{Reliability}

\section{Cronbach's Alpha and Split-Half Correlation}

The Cronbach's Alpha coefficient was calculated in order to determine the internal consistency of the Turkish translation of 108 items of 9 subscales, and the split-half correlation test was conducted to determine its consistency. The Cronbach's alpha coefficient values and the split-half correlation values of the subscales are provided in Table 6. 
Table 6 .

Cronbach's Alpha coefficients and split-half correlation values of the subscales

\begin{tabular}{|c|c|c|c|c|}
\hline & \multicolumn{2}{|c|}{ High School Sample } & \multicolumn{2}{|c|}{ Middle School Sample } \\
\hline Sub-scales & $\begin{array}{l}\text { Cronbac } \\
\text { h Alfa }\end{array}$ & $\begin{array}{c}\text { Split-half } \\
\text { Correlatio } \\
\text { n (r) }\end{array}$ & $\begin{array}{l}\text { Cronbac } \\
\text { h Alfa }\end{array}$ & $\begin{array}{c}\text { Split-half } \\
\text { Correlatio } \\
\text { n (r) }\end{array}$ \\
\hline $\begin{array}{l}\text { Attitude Toward Success in } \\
\text { Mathematics (AS) }\end{array}$ & .76 & .86 & - & - \\
\hline Mathematics as a Male Domain (MD) & .72 & .80 & & \\
\hline Mother Scale (M) & .77 & .76 & .76 & .78 \\
\hline Father Scale (F) & .79 & .79 & .79 & .82 \\
\hline Teacher Scale (T) & .74 & .75 & .74 & .72 \\
\hline Confidence Scale (C) & .82 & .86 & .89 & .81 \\
\hline Mathematics Anxiety Scale (A) & .80 & .78 & - & - \\
\hline Effectance Motivation (E) & .71 & .90 & .85 & .88 \\
\hline Mathematics Usefulness Scale (U) & .81 & .77 & .87 & .85 \\
\hline
\end{tabular}

The internal consistency coefficients above .70 are considered to be overall sufficient for scale reliability (Liu, 2003). In this context, internal consistency coefficients of the entire scale and of each subscale above .70 and the values of the Spearman Brown split-half correlation test are considered sufficient for scale reliability.

\section{DISCUSSIONS AND CONCLUSION}

In this study, reliability and validity analysis were conducted on the Mathematical Anxiety Scale, developed by Fennema and Sherman (1976). The scale consists of 9 subscales and 108 items as per its original version. The Cronbach's Alpha coefficients of the subscales calculated above 0.70 indicate that the subscales are reliable.

The conclusions of the EFA and CFA conducted to determine construct validity of the scale may be interpreted as the construct being protected as per its original and that it is sufficiently compliant to be applied in Turkey. The scale and related items of the translated scale are provided in Table 7. 
Table 7.

9 subscales and related items of the Mathematical Anxiety Scale

\begin{tabular}{|c|c|}
\hline Sub-scales & Items \\
\hline AttitudeTowardSuccess in Mathematics, (AS) & $\underline{7} \underline{8}, 24, \underline{33}, 46,54,60, \underline{64}, \underline{69}, 71, \underline{79}, 92$ \\
\hline Mathematics as a Male Domain, (MD) & $11,22,35, \underline{43}, 44, \underline{55}, \underline{59}, 73, \underline{89}, 98, \underline{100}, \underline{107}$ \\
\hline MotherScale, (M) & $3, \underline{4}, 26, \underline{29}, \underline{30}, \underline{49}, \underline{50}, 53,57, \underline{67}, 81,97$ \\
\hline FatherScale, (F) & $5,6,25,31, \underline{32}, 47, \underline{48}, \underline{58}, 61, \underline{63}, \underline{104}, \underline{108}$ \\
\hline TeacherScale, (T) & $\underline{9} 10,23, \underline{34}, \underline{45}, 56,66, \underline{82}, 83, \underline{93}, 102, \underline{103}$ \\
\hline ConfidenceScale, (C) & $1, \underline{2} \underline{12}, 27,28,51, \underline{52}, \underline{62}, 65, \underline{78}, 105, \underline{106}$ \\
\hline MathematicsAnxietyScale, (A) & $15, \underline{16}, 19,37, \underline{38}, \underline{41}, 68,74, \underline{84}, 85, \underline{90}, \underline{96}$ \\
\hline EffectanceMotivation, (E) & $\underline{17}, \underline{18}, 20, \underline{39}, 40,75, \underline{76}, \underline{87}, 88,94, \underline{99}, 101$ \\
\hline MathematicsUsefulnessScale, (U) & $\underline{13}, \underline{14}, 21, \underline{36}, 42,70, \underline{72}, \underline{77}, 80, \underline{86}, 91,95$ \\
\hline
\end{tabular}

(_) Underlined items are reverse items.

\section{Grading of the Scale}

While the higher points obtained from each subscale indicate positive attitude, lower points in "Mathematics as a Male Domain (MD)" subscale imply that men are more likely to study mathematics.

\section{References}

Aiken, L. R. (1970). Attitudes toward mathematics. Review of Educational Research, 40(4), 551-596.

Aiken, L. R. (1972). Research on attitudes toward mathematics. Arithmetic Teacher, 19(3), 229-234.

Aşkar, P. (1986). Matematik Dersine Yönelik Tutumu Ölçen Likert Tipi Bir Ölçeğin Geliştirilmesi. Eğitim ve Bilim, 11(62), 31-36.

Aydeniz, M., Cakmakcl, G., Cavas, B., Ozdemir, S., Akgunduz, D., Corlu, M. S., \& Oner, T. (2015). STEM eğitimi Türkiye raporu: Günün modası mı yoksa gereksinim mi? [A report on STEM Education in Turkey: A provisional agenda or a necessity?] [White Paper]. İstanbul, Turkey: Aydın Üniversitesi.

Bartlett, M. S. (1950). Tests of significance in factor analysis. The British Journal of Psychology, 3 (Part II), 77- 85.

Baykul, Y. (1990). İlkokul Beşinci Sinıftan Lise Ve Dengi Okulların Son Sinıflarına Kadar Matematik Ve Fen Derslerine Karşı Tutumda Görülen Değişmeler Ve Öğrenci Seçme 
Sınavındaki Başarı İle İlişkili Olduğu Düşünülen Bazı Faktörler. Ankara: ÖSYM Yayınları.

Blackweir, J. (2016). Attitudes towards mathematics: Development and validation of an online, semantically differentiated, visual analogue scale, Thesis and Coursework of The University of WesternAustralia.

Büyüköztürk, Ş. (2013). Sosyal bilimler için veri analizi el kitabl: İstatistik, araştırma deseni, SPSS uygulamaları ve yorum. (18th ed.). Ankara: Pegem Akademi Yayıncılı.

Di Martino, P., \& Zan, R. (2010). 'Me and maths': Towards a definition of attitude grounded on students' narratives. Journal of Mathematics Teacher Education, 13(1), 27-48. http://dx.doi.org/10.1007/s10857-009-9134-z

Erol, E. (1989). Prevalence and Correlates of Math Anxiety in Turkish High School Students. Yüksek Lisans Tezi, Boğaziçi Üniversitesi, İstanbul.

Etsey, Y., \& Snetzler, S. (1998). A meta-analysis of gender differences in student attitudes toward mathematics. Paper presented at the Annual Meeting of the American

Educational Research Association, San Diego, USA, 13-17 April 1998.

Fennema, E., \& Sherman, J. (1976). Fennema-Sherman mathematics attitudes scales: Instruments designed to measure attitudes toward the learning of mathematics by females and males. Journal for Research in Mathematics Education, 7(5), 324-326.

Felder, R. M., Felder, G. N., Mauney, M., Hamrin, C. E., \& Dietz, E. J. (1995). A longitudinal study of engineering student performance and retention. III. Gender differences in student performance and attitudes. Journal of Engineering Education, 84(2), 151-163.

Johnson, R. M. (2000). Gender differences in mathematics performance. Annual Meeting of the American Educational Research Association, New Orleans, LA, USA.

Jöreskog, K. G., \& Sörbom, D. (1993). LISREL 8: Structural equation modeling with the SIMPLIS command language. Hillsdale, NJ: Lawrence Erlbaum Associates Publishers.

Kaiser, H. (1974). An index of factorsimplicity.Psychometrika39: 31-36.

Kanny, M.A., Sax, L.J., \& Riggers-Pieh, TA. (2014). Investigating forty years of stem research: How explanations for the gender gap have evolved over time. Journal of Women and Minorities in Science and Engineering, 20(2), 127-148.

Khine, M. S., \& Afari, E. (2014). Psychometric properties of an inventory to determine the factors that affect students' attitudes toward mathematics. Psychology, Society, \& Education, 6(1), 1-15. Retrieved from http://psye.org/articulos/khine.pdf

LeGrand, J. C. (2013). Exploring gender differences across elementary, middle, and high school students' science and math attitudes and interest (Unpublished doctoral dissertation).

Leslie, S., Cimpian, A., Meyer, M., \& Freeland, E. (2015). Expectations of brilliance underlie gender distributions across academic disciplines. Science, 347(6219), 262265. http://dx.doi.org/10.1126/science.1261375 
Lim, S. (2012). Using history as context in pre-tertiary Singapore mathematics classrooms: Effects on achievement, motivation, attitudes and anxiety (Unpublished doctoral dissertation). University of Western Australia, Crawley, WA.

Liu (2003). Developing a Scaletomeasuretheinteractivity of websites, Journal of Advertising Research, June, 207-217.

Ma, X., \& Kishor, N. (1997). Assessing the relationship between attitude toward mathematics and achievement in mathematics: A meta-analysis. Journal for Research in Mathematics Education, 28(1), 26-47.

Mulhern, F. \& Rae, G. (1998). Development of a shortened form of the FennemaSherman mathematics attitudes scale. Educational and Psychological Measurement, 58, 295-306, Doi: 10.1177/0013164498058002012

Neale, D. (1969). The role of attitudes in learning mathematics. Arithmetic Teacher, 16(8), 631-640.

Ross, V. (2015). More than "a little bit nervous": Understanding the experiences of young women with anxiety during secondary school. (Unpublished master's thesis, Queen's University, Kingston, Ontario).

Tapia, M. (1996). The attitudes toward mathematics instrument. Paper presented at the annual meeting of the Mid-South Educational Research Association, Tuscaloosa, USA, 6-8 November 1996.

Tapia, M., \& Marsh, G. E. (2000). Effect of gender, achievement in mathematics, and ethnicity on attitudes toward mathematics. Annual Meeting of the Mid-South Educational Research Association, BowlingGreen, KY, USA.

Triandis, H. (1971). Attitude and attitude change. New York: John Wiley \& Sons, Inc.

Wigfield, A., \& Eccles, J. S. (2000). Expectancy-value theory of achievement motivation. Contemporary Educational Psychology, 25(1), 68-81. http://dx.doi.org/ 10.1006/ceps.1999.1015

Walberg, H. J., \& Haertel, G. D. (1992). Educational psychology's first century. Educational Psychology, 84, 6-19.

Yıldırım, H. H., Yıldırım, S., \& Ceylan, E. (2017) Türkiye Perspektifinden TIMSS 2015 Sonuçları. Türk Eğitim Derneği (TED). Ankara. 
Appendix: Some items from Scales

\begin{tabular}{|c|c|c|c|c|c|c|}
\hline \multicolumn{2}{|c|}{$\begin{array}{l}\text { Attitude Toward Success in Mathematics, (AS); } \\
\text { Mathematics as a Male Domain, (MD); } \\
\text { Mother Scale, (M); } \\
\text { Father Scale, (F); } \\
\text { Teacher Scale, (T); } \\
\text { Confidence Scale, (C); } \\
\text { Mathematics Anxiety Scale, (A); } \\
\text { Effectance Motivation, (E); } \\
\text { Mathematics Usefulness Scale, (U). }\end{array}$} & 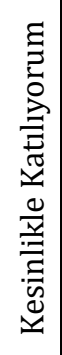 & 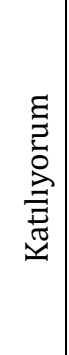 & 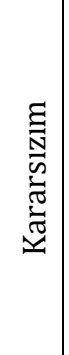 & 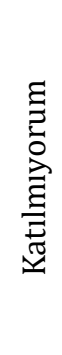 & 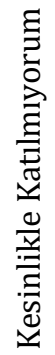 \\
\hline $\begin{array}{l}\mathrm{C}+ \\
\mathrm{C}- \\
\mathrm{C}-\end{array}$ & $\begin{array}{l}\text { Matematik çalışma konusunda, genellikle kendime güvenirim. } \\
\text { Çoğu derste fena değilim, fakat matematiği batırma konusunda } \\
\text { doğal bir yeteneğim var. } \\
\text { Matematikte hic iyi değilim. }\end{array}$ & $\begin{array}{l}5 \\
5 \\
5\end{array}$ & $\begin{array}{l}4 \\
4 \\
4\end{array}$ & $\begin{array}{l}3 \\
3 \\
3\end{array}$ & $\begin{array}{l}2 \\
2\end{array}$ & $\begin{array}{l}1 \\
1\end{array}$ \\
\hline $\begin{array}{l}\mathrm{M}+ \\
\mathrm{M}- \\
\mathrm{M}+\end{array}$ & $\begin{array}{l}\text { Annem, matematik dersinde başarılı olabileceğimi düşünür. } \\
\text { Annem, matematikle uğraşmaktan nefret eder. } \\
\text { Annem, matematik alanındaki ilerlemem ile her zaman } \\
\text { ilgilenmiștir. }\end{array}$ & $\begin{array}{l}5 \\
5 \\
5\end{array}$ & $\begin{array}{l}4 \\
4 \\
4\end{array}$ & $\begin{array}{l}3 \\
3 \\
3\end{array}$ & $\begin{array}{l}2 \\
2 \\
2\end{array}$ & $\begin{array}{l}1 \\
1 \\
1\end{array}$ \\
\hline $\begin{array}{l}\text { AS+ } \\
\text { AS- }\end{array}$ & $\begin{array}{l}\text { Matematik alanında bir ödül kazanmak gerçekten çok iyi olurdu. } \\
\text { İnsanların benim matematik konusunda zeki olduğumu } \\
\text { düşünmelerinden hoşlanmam. } \\
\text { Matematikte en yüksek notu alsaydım, bunu kimse bilmesin } \\
\text { isterdim. }\end{array}$ & $\begin{array}{l}5 \\
5\end{array}$ & $\begin{array}{l}4 \\
4\end{array}$ & $\begin{array}{l}3 \\
3\end{array}$ & $\begin{array}{l}2 \\
2\end{array}$ & $\begin{array}{l}1 \\
1\end{array}$ \\
\hline $\mathrm{T}+$ & $\begin{array}{l}\text { Baş edemediğim problemlerle karşılaștığımda, matematik } \\
\text { öğretmenleri tarafından önemsenmediğimi hissederim. } \\
\text { Matematik öğretmenlerimle matematiği kullanan bir meslek } \\
\text { hakkında konuşabilirim. } \\
\text { Matematik öğretmenleri, bana matematik alanında } \\
\text { ilerleyebileceğimi hissettirdi. }\end{array}$ & 5 & 4 & 3 & 2 & 1 \\
\hline $\begin{array}{l}\text { U- } \\
\mathrm{U}- \\
\mathrm{U}+\end{array}$ & $\begin{array}{l}\text { İş hayatımda matematiğin benim için bir önemi olmayacak. } \\
\text { Okul bittikten sonra, okuldaki matematik derslerimde ne kadar } \\
\text { başarılı olduğumun bir önemi kalmayacak. } \\
\text { Matematik, değerli ve gerekli bir derstir. }\end{array}$ & $\begin{array}{l}5 \\
5 \\
5\end{array}$ & $\begin{array}{l}4 \\
4 \\
4\end{array}$ & $\begin{array}{l}3 \\
3 \\
3\end{array}$ & $\begin{array}{l}2 \\
2 \\
2\end{array}$ & $\begin{array}{l}1 \\
1 \\
1\end{array}$ \\
\hline $\begin{array}{l}\text { A- } \\
+\mathrm{A} \\
\mathrm{A}+\end{array}$ & $\begin{array}{l}\text { Matematik, beni genellikle rahatsız ve gergin hissettirir. } \\
\text { Daha fazla matematik dersi almak (kurs, özel ders vb.) beni } \\
\text { rahatsız etmez. } \\
\text { Matematik derslerinde genellikle rahat olmuşumdur. }\end{array}$ & $\begin{array}{l}5 \\
5\end{array}$ & $\begin{array}{l}4 \\
4\end{array}$ & $\begin{array}{l}3 \\
3\end{array}$ & $\begin{array}{l}2 \\
2\end{array}$ & $\begin{array}{l}1 \\
1\end{array}$ \\
\hline $\begin{array}{l}\text { E- } \\
\text { E+ } \\
\text { E+ }\end{array}$ & $\begin{array}{l}\text { Zor bir matematik sorusunu çözmeye uğraşmak yerine, birinin } \\
\text { bana sorunun çözümünü vermesini tercih ederim. } \\
\text { Matematik bulmacalarını severim. } \\
\text { Matematik bulmacalarını severim. }\end{array}$ & $\begin{array}{l}5 \\
5 \\
5\end{array}$ & $\begin{array}{l}4 \\
4 \\
4\end{array}$ & $\begin{array}{l}3 \\
3 \\
3\end{array}$ & $\begin{array}{l}2 \\
2 \\
2\end{array}$ & $\begin{array}{l}1 \\
1 \\
1\end{array}$ \\
\hline $\begin{array}{l}\text { MD+ } \\
\text { MD- }\end{array}$ & $\begin{array}{l}\text { Geometride kadınlar da erkekler kadar başarılıdır. } \\
\text { Kadın bir matematikçinin erkeksi davranıslar sergilemesini } \\
\text { beklerim. } \\
\text { Matematik çalışmak kadınlar için de, erkekler için olduğu kadar } \\
\text { uygundur. }\end{array}$ & $\begin{array}{l}5 \\
5\end{array}$ & $\begin{array}{l}4 \\
4\end{array}$ & $\begin{array}{l}3 \\
3\end{array}$ & $\begin{array}{l}2 \\
2\end{array}$ & $\begin{array}{l}1 \\
1\end{array}$ \\
\hline $\begin{array}{l}\mathrm{F}+ \\
\mathrm{F}+ \\
\mathrm{F}-\end{array}$ & $\begin{array}{l}\text { Babam, matematiğin gördüğüm en önemli derslerden biri } \\
\text { olduğunu düşünür. } \\
\text { Babam, matematik dersinde başarılı olabileceğimi düşünür. } \\
\text { Dersten geçtiğim sürece babam matematikte ne kadar başarılı } \\
\text { olduğumu umursamadı. }\end{array}$ & $\begin{array}{l}5 \\
5 \\
5\end{array}$ & $\begin{array}{l}4 \\
4 \\
4\end{array}$ & $\begin{array}{l}3 \\
3 \\
3\end{array}$ & $\begin{array}{l}2 \\
2 \\
2\end{array}$ & $\begin{array}{l}1 \\
1 \\
1\end{array}$ \\
\hline
\end{tabular}

